\title{
PEMANFAATAN GRUP DISKUSI ONLINE \\ DALAM UPAYA PENCEGAHAN OBESITAS PADA REMAJA
}

\author{
Devi Wulandari \\ Jurusan Pendidikan Biologi, FMIPA, UNY \\ deviwulandari0512@gmail.com
}

\begin{abstract}
Intisari
Obesitas atau kegemukan pada masa remaja perlu mendapatkan perhatian khusus karena sangat berpengaruh pada pertumbuhan dan perkembangan tubuh serta dampaknya pada status gizi saat menginjak masa dewasa. Banyak sekali risiko gangguan kesehatan yang dapat terjadi pada remaja yang mengalami obesitas. Beberapa risiko masalah kesehatan tersebut perlu diperhatikan lebih serius dalam upaya tindak preventif/pencegahan.. Faktor-faktor penyebab terjadinya obesitas bersifat multifaktorial. Terdapat faktor internal dan eksternal yang mempengaruhinya. Resiko obesitas pada remaja dapat dicegah dan dikurangi dengan cara mengubah gaya hidup yang tidak sehat menjadi gaya hidup yang lebih sehat. Upaya pencegahan dapat dilakukan dengan cara memberikan pendidikan gizi kepada remaja. Penggunaan sosial media sebagai sarana pendidikan pencegahan obesitas merupakan solusi yang inovatif. Tujuan digunakannya sosial media adalah untuk menciptakan kondisi dan suasana pembelajaran yang menarik, menyenangkan dan interaktif. Materi dapat disampaikan mealalui video edukasi, poster dan animasi yang dinilai lebih efesien. Materi yang sudah dibuat disampaikan melalui group-group-group diskusi online. Penggunaan group diskusi diharapkan dapat meningkatkan motivasi remaja dalam memahami pencegahan obesitas, sehingga proses pencegahan obesitas dapat berjalan lebih efektif dan efesien. Pada akhirnya diharapkan upaya pencegahan obesitas pada remaja dapat mendapatkan hasil, dengan indikator semakin banyaknya remaja yang melek akan bahaya obesitas dan pentingnya pencegahan obesitas.
\end{abstract}

Kata kunci: obesitas, remaja, pencegahan, group diskusi online

\section{PENDAHULUAN}

Obesitas atau kegemukan merupakan suatu penyakit serius yang dapat mengundang penyakit yang lebih serius dan berbahaya. Obesitas saat ini menjadi permasalahan dunia bahkan WHO mendeklarasikan sebagai epidemic global. Menurut Pingkan Palilingan (2010), banyak sekali risiko gangguan kesehatan yang dapat terjadi pada remaja yang mengalami obesitas. Beberapa risiko masalah kesehatan tersebut perlu diperhatikan lebih serius dalam upaya tindak preventif/pencegahan. 
Jumlah penderita obesitas di dunia selalu megalami peningkatan setiap tahunnya. Peningkatan penderita obesitas juga terjadi di Indonesia, bahkan saat ini Indonesia menempati peringkat ke-10 di dunia. Berdasarkan profil kesehatan dasar tahun 2013 dapat diketahui bahwa obesitas pada remaja secara nasional juga mengalami peningkatan setiap tahunnya. Rata-rata penderita obesitas pada tahun 2007 sebesar 10,3\% naik menjadi 15,4\% pada tahun 2013.

Masalah gizi pada masa remaja perlu mendapatkan perhatian khusus karena sangat berpengaruh pada pertumbuhan dan perkembangan tubuh serta dampaknya pada status gizi saat menginjak masa dewasa. Dampak lain yang ditimbulkan akibat terjadiya obesitas pada remaja adalah body image negatif. Body image didefinisikan sebagai presepsi, pikiran dan perasaan seseorang tentang bentuk dan ukuran tubuhnya. Body image negatif merupakan gangguan serius yang dapat berpengaruh terhadap kesehatan mental, perilaku makan dan keterbatasan aktivitas fisik (Setyawati dan Setyowati, 2015). Menurut Contreras (2015), body image negatif umumnya terjadi pada masa remaja. Heinberg dan Thompson dalam Emilia (2009) mengemukakan dasar untuk mencegah timbulnya body image negatif pada remaja adalah melalui pendidikan gizi kesehatan Pendidikan gizi kesehatan efektif apabila menggunakan media yang menarik.

Media online mempunyai daya tarik tersendiri bagi setiap kalangan, tidak terkecuali pada remaja. Berdasarkan hasil riset yang dilakukan oleh Kominfo dalam penelusuran pengguna aktivitas online paling tinggi pada anak usia remaja. Dalam berbagai media online terdapat fitur dan group-group diskusi yang dapat mempermudah dalam penyampaian berbagai macam materi yang disusun lebih ringan, dikemas populer, menarik dan efektif serta tidak membosankan guna pembelajaran gizi kesehatan pada remaja putri untuk pencegahan obesitas.

\section{METODE}

Penelitian ini diawali dengan melakukan kajian terhadap sejumlah literatur yang dapat mendukung pendekatan analisis, meliputi: data riset obesitas dan pengunaan media online, nilai kecukupan konsumsi pangan, faktor dan pencegahan obesitas, pengemasan materi pembelajaran yang menarik dan prnggunaan forum diskusi online untuk pendidikan. sumber kajian adalah berupa buku refrensi, jurnal ilmiah yang dipublikasikan, refrensi website yang diakses melalui internet dan media sosial instagram. 


\section{HASIL PENELITIAN DAN PEMBAHASAN}

Kecukupan konsumsi pangan dapat dilihat dengan menghitung tingkat kecukupan gizinya. Angka kecukupan gizi adalah nilai yang menunjukkan jumlah zat gizi yang diperlukan tubuh untuk hidup sehat setiap hari. Angka kecukupan gizi berguna sebagai nilai rujukan yang digunakan untuk perencanaan dan penilaian konsumsi makanan dan asupan gizi bagi orang sehat, agar tercegah dari defisiensi ataupun kelebihan asupan zat gizi (Hardinsyah, et al., 2016: 20-21). Angka kecukupan gizi makronutrien (protein, lemak dan karbohidrat) untuk usia remaja dapat dilihat pada Tabel 1. Angka kecukupan gizi mikronutrien (vitamin dan mineral) dapat dilihat pada Tabel 2.

Tabel 1. Angka Kecukupan Gizi Makronutrien yang Dianjurkan (Per Orang Per Hari) untuk Orang Indonesia

\begin{tabular}{|c|c|c|c|c|c|c|}
\hline $\begin{array}{c}\text { Usia } \\
(\text { Tahun })\end{array}$ & $\begin{array}{c}\text { BB } \\
(\mathrm{kg})\end{array}$ & $\begin{array}{c}\text { TB } \\
(\mathrm{cm})\end{array}$ & $\begin{array}{c}\text { Energi } \\
(\mathrm{kkal} / \mathrm{hari})\end{array}$ & $\begin{array}{c}\text { Protein } \\
(\text { gram/hari })\end{array}$ & $\begin{array}{c}\text { Lemak } \\
(\text { gram/hari })\end{array}$ & $\begin{array}{c}\text { Karbohidrat } \\
(\text { gram/hari })\end{array}$ \\
\hline $\begin{array}{c}\text { Perempuan } \\
16-18\end{array}$ & 50 & 154 & 2200 & 50 & 70 & 300 \\
\cline { 2 - 7 } & 54 & 159 & 2250 & 56 & 75 & 309 \\
\hline
\end{tabular}

Tabel 2. Angka Kecukupan Gizi Mikronutrien yang Dianjurkan (Per Orang Per Hari) untuk Orang Indonesia

\begin{tabular}{|c|c|c|c|c|c|c|c|c|c|c|c|c|}
\hline \multirow[b]{2}{*}{$\begin{array}{c}\text { Usia } \\
\text { (Tahun) }\end{array}$} & \multirow[b]{2}{*}{$\begin{array}{l}\text { BB } \\
(\mathrm{kg})\end{array}$} & \multirow[b]{2}{*}{$\begin{array}{l}\mathrm{TB} \\
(\mathrm{cm})\end{array}$} & \multicolumn{6}{|c|}{ Vitamin } & \multirow{2}{*}{$\begin{array}{l}\text { Tam } \\
\text { in } \\
(\mathrm{mg})\end{array}$} & \multirow{2}{*}{$\begin{array}{c}\text { Ribo } \\
\text { flavi } \\
\mathrm{n} \\
(\mathrm{mg})\end{array}$} & \multirow{2}{*}{$\begin{array}{c}\text { Asam } \\
\text { folat } \\
\text { (ug) }\end{array}$} & \multirow{2}{*}{$\begin{array}{c}\text { Pirid } \\
\text { oksi } \\
\mathrm{n} \\
(\mathrm{mg})\end{array}$} \\
\hline & & & $\begin{array}{c}\mathrm{A} \\
(\mathrm{RE})\end{array}$ & $\begin{array}{c}\text { D } \\
(\mathrm{ug})\end{array}$ & $\begin{array}{c}\mathrm{E} \\
(\mathrm{mg})\end{array}$ & $\begin{array}{r}\mathrm{K} \\
\text { (ug) }\end{array}$ & $\begin{array}{l}\text { B12 } \\
\text { (ug) }\end{array}$ & $\begin{array}{c}\mathrm{C} \\
(\mathrm{mg})\end{array}$ & & & & \\
\hline \multirow{3}{*}{$\begin{array}{c}\text { Perempuan } \\
16-18\end{array}$} & \multirow{3}{*}{50} & \multirow{3}{*}{154} & 600 & 5 & 15 & 55 & 2,4 & 75 & 1,1 & 1 & 400 & 1,2 \\
\hline & & & 500 & 5 & 15 & 55 & 2,4 & 75 & 1 & 1,1 & 400 & 1,3 \\
\hline & & & \multicolumn{2}{|c|}{$\begin{array}{l}\text { Kalsium } \\
\text { (mg) }\end{array}$} & \multicolumn{2}{|c|}{ Besi (mg) } & \multicolumn{2}{|c|}{$\begin{array}{l}\text { Yodium } \\
\text { (ug) }\end{array}$} & \multicolumn{2}{|c|}{ Seng (mg) } & \multicolumn{2}{|c|}{$\begin{array}{c}\text { Selenium } \\
\text { (ug) }\end{array}$} \\
\hline \multirow[t]{2}{*}{$19-29$} & \multirow[t]{2}{*}{54} & \multirow[t]{2}{*}{159} & \multicolumn{2}{|c|}{1000} & \multicolumn{2}{|c|}{26} & \multicolumn{2}{|c|}{150} & \multicolumn{2}{|c|}{14} & \multicolumn{2}{|c|}{30} \\
\hline & & & \multicolumn{2}{|c|}{800} & \multicolumn{2}{|c|}{26} & \multicolumn{2}{|c|}{150} & \multicolumn{2}{|c|}{9,3} & \multicolumn{2}{|c|}{30} \\
\hline
\end{tabular}

Sumber: Depkes RI (2013: 209).

Pencegahan obesitas dapat dilakukan dengan mengatur menu makanan yang dikonsumsi sehari-hari yaitu dengan menu sehat. Menu sehat adalah menu yang mengandung 
makanan yang sehat, higienis dan bergizi (Hanifa \& Luthfeni, 2006: 56). Memilih bahan makanan yang tepat merupakan langkah yang tepat untuk pencegahan obesitas. Bahan makanan yang dikonsumsi merupakan bahan makanan makronutrien (karbohidrat, lemak dan protein) yang rendah kalori dan tinggi serat. Konsumsi sayur dan buah sebagai komponen paling penting untuk penderita obesitas. Selain mengandung karbohidrat sebagai energi, sayur dan buah juga mengandung serat yang sangat dibutuhkan oleh tubuh.

\section{Faktor-Faktor Penyebab Obesitas}

Faktor-faktor penyebab terjadinya obesitas bersifat multifaktorial. Terdapat faktor internal dan eksternal yang mempengaruhinya. Faktor internal merupakan penentu sifat yang diturunkan dari kedua orang tuanya, sedangkan faktor eksternal merupakan faktor lingkungan yang dapat mempengaruhi gaya hidup seseorang. Berikut merupakan beberapa gaya hidup yang dapat mempengaruhi terjadinya obesitas, yaitu:

1. Porsi Makan Berlebih dan Kualitas Makanan

Menurut Harjatmo (2017), obesitas terjadi karena adanya ketidakseimbangan antara energi yang masuk dengan energi yang keluar dan merupakan akumulasi simpanan energi yang berubah menjadi lemak. Porsi makan yang berlebih terutama makanan yang padat energi dapat menyebabkan terjadinya penimbunan energi. Energi yang berlebih akan disimpan di dalam tubuh sebagai cadangan penghasil energi yang sewaktu-waktu dapat digunakan apabila tubuh kekurangan sumber energi dari konsumsi makan.

2. Kurang Aktivitas Fisik dan Olahraga

Kurangnya aktivitas fisik dan olahraga menyebabkan energi yang masuk lebih besar daripada energi yang dikeluarkan. Kelebihan energi tersebut disimpan dalam tubuh dalam bentuk lemak. Menurut Purwati (2005), energi yang masuk berlebihan dan tidak diimbangi dengan aktivitas fisik yang seimbang akan memudahkan seseorang menjadi gemuk. Aktivitas fisik diperlukan untuk proses pembakaran energi tubuh melalui mekanisme metabolisme tubuh. Gaya hidup dengan aktivitas fisik yang rendah berpengaruh terhadap kondisi tubuh seseorang.

3. Kebiasaan Makan Fast Food dan Cemilan

Fast food dan cemilan merupakan makanan tinggi gula, garam, lemak dan minyak. Remaja memiliki kecenderungan lebih aktif makan diluar rumah dan banyak mendapat pengaruh dalam pemilihan makanan yang akan dimakan serta lebih sering ingin mencobacoba, dikarenakan ingin mengikuti trend yang dianggap kekinian. Kecenderungan lebih 
aktif makan diluar menyebabkan terjadinya peningkatan konsumsi fast food dan cemilan. Menurut Kurdanti, et al. (2015), konsumsi fast food pada remaja yang semakin sering berisiko 2,47 kali mengalami obesitas dibandingkan dengan remaja yang jarang mengonsumsi fast food.

4. Hormon

Hormon dan hasil metabolisme akan meningkat di darah dan jaringan tubuh saat melakukan aktivitas olahraga. Menurut Radomski (1998), banyak faktor yang mempengaruhi regulasi pelepasan hormon sewaktu olahraga yang menyebabkan peningkatan metabolisme. Peningkatan metabolisme dapat membakar lemak di dalam tubuh dan membebaskan panas (Darmoutomo, E., 2007: 31).

5. Psikologis

Faktor psikologis yaitu emosional berhubungan erat dengan rasa lapar dan nafsu makan. Hal ini disebabkan karena sejumlah hormon akan disekresi sebagai tanggapan dari keadaan psikologis sehingga terjadi peningkatan metabolisme energi yang dipecah dan digunakan untuk melakukan aktivitas, namun jika seseorang yang mengalami stress tidak melakukan aktivitas fisik yang mampu membakar energi maka kelebihan energi tersebut akan disimpan sebagai lemak. Proses ini akan menyebabkan glukosa darah menurun sehingga menyebabkan rasa lapar pada orang yang sedang mengalami tekanan psikologis (Purwati, S., 2005: 42).

6. Tidak Cukup Tidur

Berdasrkan penelitian yang dilakukan oleh Warwick Medical School di University of Warwick, peneliti menemukan bahwa seseorang yang tidak cukup tidur dapat berisiko dua kali lipat untuk mengalami obesitas. Kurang tidur dapat menyebabkan obesitas melalui peningkatan nafsu makan akibat dari perubahan hormonal.

\section{Cara Pencegahan Obesitas}

Resiko obesitas pada remaja dapat dicegah dan dikurangi dengan cara mengubah gaya hidup yang tidak sehat menjadi gaya hidup yang lebih sehat. Berikut ini merupakan beberapa gaya hidup sehat yang dapat diterapkan sebagai upaya pencegahan obesitas:

1. Rajin Beraktivitas dan Berolahraga

Obesitas dapat dicegah dengan cara tidak menerapkan gaya hidup kurang gerak atau yang biasa disebut dengan sedentary life style serta aktif melakukan kegiatan 
olahraga. Olahraga yang dianjurkan merupakan olahraga yang bersifat aerobik atau menggunakan oksigen dalam pembentukan energinya.

2. Mengurangi Porsi Makan dan Mengatur Kualitas Makanan

Porsi makan yang dikonsumsi sebaiknya disesuaikan dengan kebutuhan tubuh agar energi yang masuk tidak lebih banyak dari energi yang dikeluarkan. Kualitas dari makanan yang dikonsumsi juga perlu diperhatikan, selain zat gizi makronutrien sebagai penghasil energi, maka konsumsi makanan juga harus memperhatikan kebutuhan gizi mikronutrien seperti zat besi, vitamin, mineral, dll.

3. Mengurangi Konsumsi Fast Food dan Cemilan

Fast food dan cemilan merupakan makanan yang banyak mengandung gula, lemak dan garam. Konsumsi fast food dan cemilan yang berlebih menyebabkan risiko obesitas meningkat.

4. Mengatur Pola dan Waktu Tidur

Remaja yang mempunyai pergaulan yang luas harus pintar mengatur waktu dalam berkegiatan tidak terkecuali waktu dan pola tidur. Waktu dan pola tidur berkaitan erat dengan kejadian obesitas. Saat tidur kebutuhan energi akan berkurang karena minim aktivitas (Safitri, A. M., 2018).

\section{Solusi Pencegahan Obesitas dengan Pemanfaatan Group Diskusi Online}

Dewasa ini teknologi semakin berkembang pesat, terutama perkembangan perangkat telekomunikasi serta fitur-fitur telekomunikasi yang semakin canggih menyebabkan banyak kalangan masyarakat yang memanfaatkannya tidak terkecuali pada kalangan remaja. Remaja memanfaatkan untuk berintraksi dengan berbagai orang, baik yang dikenal maupun tidak dikenal serta tidak terbatas jarak dan waktu melalui berbagai macam sosial media. Terdapat beberapa media sosial yang sangat populer bagi kalangan remaja antara lain whatsapp, instagram, line, twiter, youtube, dll. Perkembangan sosial media dapat berkembang menjadi hal yang berdampak positif dan negatif tergantung dari penggunaanya. Dampak negatif dapat terjadi apabila penggunanya tidak bijak dalam memanfaatkan media sosial, sedangkan dampak positif dapat terjadi apabila penggunanya bijak dalam memanfaatkan media sosial untuk halhal yang lebih bermanfaat salah satunya adalah penggunaan group-group diskusi online untuk penyuluhan atau pembelajaran terhadap pencegahan obesitas pada remaja.

1. Penyampaian Materi

Penggunaan animasi memiliki beberapa fungsi seperti hiburan, iklan dan pendidikan (Cingi, 2013). Animasi adalah alat komunikasi visual yang berkembang dan 
merupakan salah satu bentuk presentasi bergambar berupa simulasi gambar bergerak. Animasi sangat efektif digunakan dalam penyampaian materi karena dapat meningkatkan daya tarik serta dapat membangkitkan motivasi dan minat seseorang dalam proses belajar tentang pendidikan gizi yang diberikan. Sehingga perhatian, konsentrasi, imajinasi, dan pemahaman terhadap materi yang diberikan meningkat.

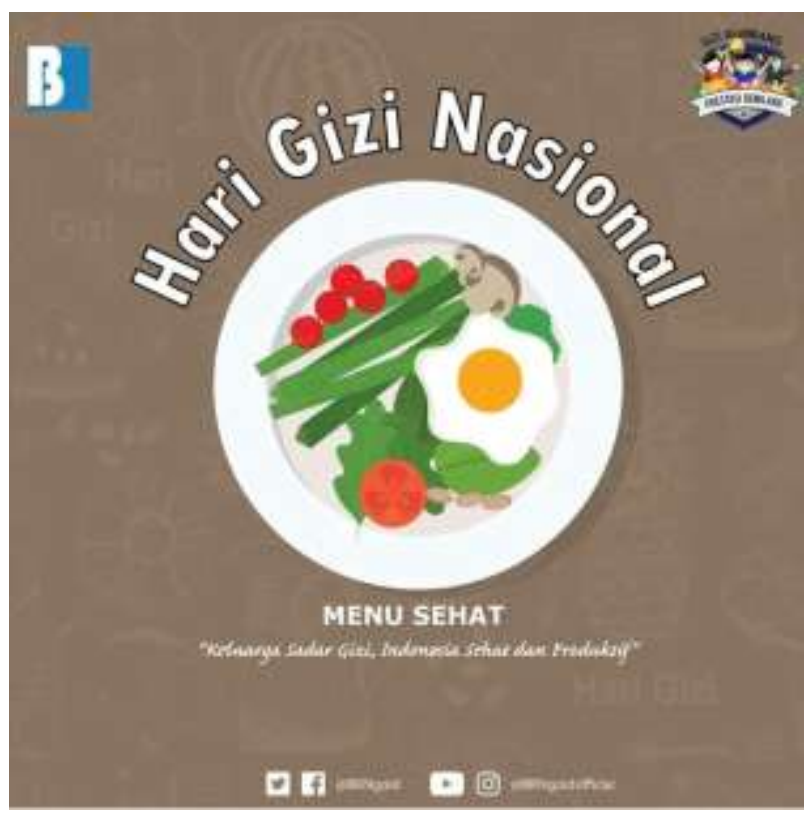

Gambar 1. Contoh Pencegahan Obesitas Melalui Animasi ttps://youtu.be/VLJrshSEdTA

Penggunaan video edukasi sebagai media pembelajaran pencegahan obesitas adalah untuk menciptakan kondisi dan suasana pembelajaran yang menarik, menyenangkan dan interaktif. Penggunaan video edukasi dinilai lebih efesien dibandingkan dengan penyampaian secara konvensional. Video edukasi ini dapat di sebarkan melalui media sosial. Media sosial sangat potensial digunakan sebagai tempat pembelajaran melalui video edukasi, dikarenakan sangat populer bagi semua kalangan terutama kalangan remaja. Penggunaan media sosial sebagai tempat pembelajaran melalui video edukasi dinilai sangat praktis, inovatif, interaktif, ekonomis dan sheareable (dapat disebarkan).

Penyampaian materi juga dapat dilakukan menggunakan poster. Poster merupakan kombinasi visualisasi yang kuat antara warna, tulisan dan gambar dengan maksud untuk menangkap perhatian orang, akan tetapi cukup lama menanamkan gagasan yang berarti di dalam ingatan banyak orang. Penggunaan poster dalam pendidikan kesehatan adalah sebagai pendorong atau motivasi kegiatan belajar mengajar yang menyenangkan. Peringatan tentang obesitas melalui poster akan membantu menyadarkan remaja sehingga 
diharapkan dapat mengubah perilaku remaja dalam praktiknya sehari hari, dengan begitu tingkat kejadian obesitas dapat ditekan dan dikurangi.

2. Diskusi Online untuk Pencegahan Obesitas

Sosial media yang populer saat ini memungkinkan penggunanya untuk membuat group-group diskusi untuk berbagai kepentingan terutama pada aplikasi whatsapp. Sebagai sosial media chat, whatsapp memungkinkan penggunanya untuk saling berkomunikasi, berintraksi serta berdiskusi secara online melalui share video, gambar, artikel dan animasi. Penggunaan sosial media secara online mempunyai kelebihan karena tidak ada keterbatasan waktu dan tempat, sehingga dinilai sangat praktis dan efesien. Pembuatan group-group diskusi online dapat digunakan untuk penyampaian berbagai macam materi salah satunya materi tentang pencegahan obesitas pada remaja. Aplikasi whatsapp juga memungkinkan penggunanya untuk saling bertukar informasi, penyebaran informasi serta dapat digunakan sebagai forum diskusi belajar tentang berbagai macam materi yang diperoleh dari berbagai sumber.

Penggunaan group diskusi online dinilai sangat penting dalam upaya pencegahan obesitas pada remaja. Group diskusi online dapat memfasilitasi kegiatan penyampaian materi dan diskusi dalam upaya pencegahan obesitas pada remaja dan dinilai lebih efektif dan efesien. Penyampaian materi melalui group diskusi online diharapkan mampu memberikan manfaat untuk menciptakan pembelajaran yang lebih konkret, memperluas cakrawala, memberikan informasi yang akurat dan merangsang untuk berfikir kritis melalui diskusi secara bersama-sama.

\section{SIMPULAN}

Upaya pencegahan obesitas pada remaja akan lebih mudah dipahami melalui pendidikan kesehatan dengan pembelajaranya yang ditunjang dengan sarana media yang tepat. Dalam upaya pencegahan obesitas pemilihan dan penggunaan sumber belajar serta materi perlu dipersiapkan secara optimal sesuai dengan topik permasalahan yang akan didiskusikan. Selain itu perlu dirancang bahan ajar untuk pembelajaran yang lebih bervariasi, inovatif, menarik dan efesien. Adanya upaya pencegahan obesitas menggunakan media online metode ini diharapkan lebih banyak orang yang peduli dengan permasalahan obesitas pada remaja, sehingga dapat dimanfaatkan sosial media melalui fitur group diskusi online yang ada di dalamnya. Penggunaan group diskusi diharapkan dapat meningkatkan motivasi remaja dalam memahami pencegahan obesitas, sehingga proses pencegahan obesitas dapat berjalan lebih efektif dan efesien. Pada akhirnya diharapkan upaya pencegahan obesitas pada remaja dapat mendapatkan 
hasil, dengan indikator semakin banyaknya remaja yang melek akan bahaya obesitas dan pentingnya pencegahan obesitas.

\section{DAFTAR PUSTAKA}

Cingi, C. 2013. Computer Animation in Teaching Surgical Procedures. Jurnal Procedia Social and Behavioral Sciences, Vol.103, 230-237.

Contreras, S., Sabitson, C., O’Loughin, E., et al. 2015. Body Image Emotions, Perceptions and Cognitions Distinguish Physically Active and Inactive Smokers. Jurnal Preventive Medicine Reports, Vol.2, 141-145.

Darmoutomo, E. 2007. Mencegah Penyakit Akibat Kegemukan dengan Asupan Nutrisi. http:/www.obesitas.web.id/news.html.

Emilia, E. 2009. Pengetahuan, Sikap dan Praktek Gizi pada Remaja dan Implikasinya pada Sosialisasi Perilaku Hidup Sehat. Jurnal Media Pendidikan Gizi dan Kuliner, Vol.1(1), 1-10.

Harjatmo, T. P., Par'i, H. M., Wiyono, S. 2017. Bahan Ajar Gizi: Penilaian Status Gizi. Jakarta: Kementrian Kesehatan Republik Indonesia.

Instagram @p2ptmkemenkesRI (diakses pada 15 Januari 2019)

Kurdanti, W., Suryani, I., Syamsiatun, N.H., et al. 2015. Faktor-Faktor yang Mempengaruhi Kejadian Obesitas Pada Remaja. Jurnal Gizi Klinik Indonesia., Vol.11, 179-190.

Pingkan, P. 2010. “Apakah Anak Anda Obesitas?”, Betterhealth Tahun 2 Edisi 3. http://www.ekahospital.com/uploads/bulletins/final/\%/20/draf.pdf. (diunduh 15 Januari 2019)

Purwati, S. 2005. Perencana Menu Untuk Penderita Kegemukan. Jakarta: Penebar Swadaya.

Safitri, A. M. 2018. Bagaimana Tidur 7 Sampai 8 Jam Sehari Memengaruhi Tubuh Kita. http://www.hallosehat.com. (diunduh 23 Januari 2019).

Setyawati, V \& Setyowati, M. 2015. Karakter Gizi Remaja Putri Urban dan Rural di Provinsi Jawa Tengah. Jurnal Kesehatan Masyarakat, Vol.11, 43-52. 